\title{
Discussion on the Influence of Postmodern Artistic Ideological Trend on Contemporary Ceramic Art
}

\author{
Changzong Shao \\ College of Ceramic Art \\ Jingdezhen Ceramic Institute \\ Jingdezhen, Jiangxi, China 333403
}

\begin{abstract}
Postmodern artistic ideological trend focuses on the main form of art and the technique innovation in the process of creation. The spring up of this ideological trend brings great conflict to the development of contemporary ceramic art. Postmodern artistic ideological trend, as a kind of multiple values-oriented academic ideological trends, on the one hand lays emphasis on the cultural venation nature of history and on the other hand, does not rigidly follow the traditional mode of thinking. Contemporary ceramic art also continuously develops and progresses under the impact of this ideological trend, on the one hand laying emphasis on the main features of contemporary ceramic art that was back to nature and on the other hand, paying attention to the continuous innovation of ceramic products. Postmodernism artistic ideological trend sparkplugs diversification value mode of natural existence and man-made innovation, the influence of this mode on contemporary ceramic art manifests the cultural sharing and humanistic care in the creation process of contemporary ceramic art.
\end{abstract}

\section{Keywords—postmodern art; ceramic art; cultural diversity}

\section{INTRODUCTION}

The cultural background of the development of postmodernism has been constantly developing and multiplying, and along with the changes of the surrounding environment, the art creation has been also constantly developing and multiplying. The continuous development of contemporary ceramic art manifests its breadth of spirit that wide heart embraces all with its gorgeous and colorful form. For the expression form, the creation and development of contemporary ceramic art was at one time influenced by the ideological trend of modernism. Some great masters creator having made their own contribution to the pure aesthetic of ceramic culture by their own practice of creative art. On account to the impact of development of the times, cultural background and personal reasons, contemporary ceramic art was left some blank and trapped within a certain boundary line, which left enough room and possibility that went beyond boundary line for the continued development of contemporary ceramic art under the impact of postmodernism ideological trend. The impact of postmodernism ideological trend on contemporary ceramic art is mainly embodied in the break of the restrictions and barriers of the development of contemporary ceramic art. Postmodernism ideological trend is a critical inheritance of modernist ideological trend. As it increases by some new things on the basis of the fine factors of modernism ideological trend, it fully reflects the achievements of the current cultural development and has a high level of generalization, which could give an extensive guidance for practice. The expression form of contemporary ceramic art under the impact of postmodernism also achieves great development which manifests the value and charm with rich and colorful and diversified form on the basis of inheritance of the original expression form of contemporary ceramic art and interprets the harmonious development between human and nature so as to forms the characteristics that return to original nature and have cultural atmosphere and actually reflects contemporary cultural atmosphere and humanistic characteristics. In the sense of contemporary ceramic art, postmodernism is far less a generalization of cultural phenomena than a form of ideological trend and movement of art design. Letting alone how deep and broad the impact of postmodernism on the field of art and design, it ultimately brings art design to a certain social and cultural atmosphere so that today's life culture can be integrated during the process of artistic creation. The above characteristics of postmodernism ideological trend has brought inevitable impact to the design of contemporary ceramic art, which makes the contemporary ceramic art constantly adjust creation method and fully displays developmental direction of the life culture and artistic atmosphere to make the contemporary ceramic art more practical significance.

\section{THE IMPACT OF POSTMODERNISM ON THE CHARACTERISTIC OF CONTEMPORARY CERAMIC ART CREATIVE CONCEPT}

The impact of postmodernism on the creation characteristics of contemporary ceramic art is mainly reflected in the following aspects: (1). letting the original intention and elements of the creation return. Contemporary ceramic art under the impact of postmodernism put forward the idea of " life ceramic of creation" so that contemporary ceramic art on the one hand fully manifests the infinite charm of the art masterpiece and on the other hand the creative resultant of that could be served the majority of people's lives and promotes great development and progress of people's lives on the aspects of material and spirit. Nowadays, the creation of contemporary ceramic art is constantly returning to its original intention and elements of creation. From the perspective of life and culture and art aesthetics, it constantly discovers the direction and form that contemporary ceramic art should serve rather than 
discovers use value of contemporary ceramic art to expand production and needs from the design point of view of contemporary ceramic art. In short, the impact of postmodernism artistic ideological trend makes creation of contemporary ceramic art change the original style - from originally motivating people's needs by contemporary ceramic art to creating new artistic achievements by the fusion of life and cultural element(from the people's practical needs). The continuous changes of the forms of contemporary ceramic art are the continuous returning manifestation of the original intention and the elements that create ceramic art. The object of "ceramic of life", which is an important guide for the creation of contemporary ceramic art, advocates that creation of contemporary ceramic art adopts traditional technology and methods. The service objects of contemporary ceramic art constantly point to the masses of people and the inspiration of that comes from people's real life and contemporary cultural atmosphere. The creation concept of "ceramic of life" makes all the creative elements of contemporary ceramic art come from people's living environment and natural environment, meets personalized use function needs and aesthetic needs of human being, and fully respects the objective existence of man and nature. (2). Contemporary ceramic art pay close attention to nature and the future. The contemporary ceramic art under the impact of postmodernism ideological trend has broken the previous mode of "geometrization", "stereotype" and mass production, which in the process of creation pay more attention to the natural laws, the objective existence of the environment and individual choice, and give sufficient consideration to mode and form of motion during the process of creation by people. In the process of creation, elements should be looking for in cultural environment, natural environment and the law with the greatest efforts to give full play to artistic and technical ability and the level on this basis. The contemporary ceramic art under the impact of postmodernism is profoundly calling to the people. Our development should be based on harmonious development between man and nature, in the progress of which nature and itself should not be sacrificed as the expense, nor should it blindly and recklessly develop. Therefore, it can be seen that the contemporary ceramic art under the impact of postmodernism fully takes into account the objective reality and the mutual relations of man and nature and pays more attention to the future of nature and society.

\section{THE DiVERSIFICATION MOdE CREATED BY CERAMIC} UNDER THE IMPACT OF POSTMODERNISM IDEOLOGICAL TREND

An idea advocated by postmodernism ideological trend is keeping the existence and development of a diversification world on the basis of present social culture. As a representative of the material and spiritual civilization of this era, the contemporary ceramic art is subjected to the impact of postmodernism ideological trend and the creation process is also constantly entering into the diversification mode.

\section{A. Coexistence and Intergrowth between History and Present As Well As Universality and Individuality}

Postmodernism, an ideological trend developed by criticism and inheritance on the basis of modernism, gets rid of the stale and bring forth the fresh on the basis of the inheritance of the fine traditions of history and culture. Under the impact of this ideological trend, the development of contemporary ceramic art also appears the coexistence mode between history and present. On the basis of inheritance, contemporary ceramic art that has the fine history continuously reviews its existing deficiencies, fully considers needs of the current human activities, and innovates and develops contemporary ceramic art. On the one hand, the development of contemporary ceramic art fully affirms the objective existence of history and the reality, and continuously develops ceramic culture and creation of contemporary ceramic art on the basis of full respect for the objective existence of history and the reality. On the other hand, now the contemporary ceramic culture has been widely developed and created and has organic combination with positive thoughts, so that all nationality of the world actively joins the current trend of the creation of contemporary ceramic art.

\section{B. The Pursuit of Cultural Sharing and Humanistic Care}

Contemporary ceramic art, whether from the content, form, style and features or means and methods of expression, is subject to the profound impact of postmodernism ideological trend. The contemporary ceramic art not only absorbs the universality of postmodernism on the aspect of creation, but also meanwhile shows the diversity that previous creation can not go beyond on the aspect of means and methods of expression. In the creation of ideas, it not only inherits the objectivity, simplicity and preciseness of original creative thought, but also carries forward the mode of subjectivity, imagination, freedom and diversity in current society and culture. In short, under the impact of postmodernism ideological trend, contemporary ceramic art not only embodies the sharing of human culture but also considers individuation of human activities in different periods, giving expression to the humanistic care.

\section{CONCLUSION}

The emergence and development of postmodernism ideological trend and the continuous development of contemporary ceramic art are the product of continuous development of current social culture. The cultural inheritance, development and universality advocated by the postmodernism ideological trend determine universality and coexistence of history and the present of contemporary ceramic art. The idea of objective existence and harmonious development of man and nature that are taken seriously by postmodernism ideological trend decide that now ceramic should fully consider nature universality and the individuality of human activities and embody the symbiosis mode of individuality and universality of contemporary ceramic art. The inclusion of cultural diversity in postmodernism determines diversification mode of the development of contemporary ceramic art. In a word, under the influence of postmodernism ideological trend, now the contemporary ceramic art is constantly adjusting cultural development manner and artistic creation mode so as to could more conform to the objective existence of man and nature and expansibility of society and culture. 


\section{REFERENCES}

1] Hu Changchun. Status Quo and Thinking - About Modern Ceramic Art Creation of the Current Jingdezhen [J]. Hundred Schools in Arts. 2011(01).

[2] Hong Zhongwen. Discussion on the Utilization of Thought and Aesthetic Function during the Ceramic Creation [J]. Jingdezhen Ceramic. 2009 (04).

[3] Guo Wenlian. Discussion on Thinking Method of Modern Ceramic Art Creation. Journal of Ceramics, 1996, (4). 